\title{
Investigating the Market Interest Rate on Commercial Banks Financial Performance in Bangladesh
}

\author{
Debashis Saha $^{\star 1}$, Prodip Chandra Bishwas ${ }^{1}$, Md. Mustofa Ahmed Sumon ${ }^{2}$ \\ ${ }^{1}$ Department of Finance and Banking, Faculty of Business Studies, Jahangirnagar University, Savar, Dhaka \\ 1342 Bangladesh \\ 2 Department of Business Administration, Bangladeshi Army University of Engineering and Technology, \\ Qadirabad Dayanrampur, Natore 6431 Bangladesh
}

\begin{abstract}
The banking sector is the most vital partner of development for countries' economies. It has a remarkable contribution to the country's Gross Domestic Product. This study investigates the relationship between the market interest rate and commercial banks' financial performance. As Bangladesh's banking industry is growing, it is vital to maintain a more robust profitability level for its financial stability and soundness. Banks have some determinants that have a significant impact on their performance. The convenience sampling method is used to select the targeted sample. The study includes the time series data of eight years of fifteen commercial banks listed on the Dhaka Stock Exchange in Bangladesh. Multiple variable linear regression and correlation analysis are performed to examine the relationship of market interest rate with banks' profitability with statistical software, IBM SPSS version 25, and Microsoft excel. The study explored that the market interest rate has a significant positive impact on banks' profitability. It is also found that the lending rate and interest rate spread are significantly correlated with the banks' financial performance. The study recommended that banks make their investment to make a higher profit margin to enhance their management and financial soundness efficiency.
\end{abstract}

Keywords: Market Interest Rate, Profitability, Lending Rate, Investment, Bangladesh

JEL Classification: E43, E52, G21S

Paper Type: Research

* Corresponding author: E-mail: debashissaha1986@gmail.com 


\section{INTRODUCTION}

The banking sector is the most vital partner of development for countries' economies. It has a remarkable contribution to the country's Gross Domestic Product (GDP). The country's banking sector reduces unemployment by creating more employment for the country and creating and providing its capital. In Bangladesh, the banking sector is the fastest growing industry, full of State-Owned Commercial Banks, Specialized Banks, Private Commercial Banks (PCBs), and Foreign Commercial Banks. Monetary Intermediation (Banks), a contribution to Bangladesh's GDP, is 3.35 percent and 3.25 percent in the financial year of 2018-2019 and 2019-2020, respectively (Bangladesh Bureau of Statistics). Therefore, it is necessary to think about the health of the banking sector. Banks have to make a substantial interest rate spread along with other income. It is the primary source of income for the banking firms for the banks' sustainability. The more profitable a bank is, the more sustainable it will be. In this sector, market interest rates often play the role of attaining profitability, ensuring the banks' soundness and financial stability. Commercial Bank of Bangladesh provided their service with a vision to serve people with modern and innovative banking products and services at affordable charge. Tan \& Floros (2012) x-rays that the banking regulatory authority should further drive the banks' capital to raise the Net Interest Margin (NIM) to make substantial financial profitability for the banks' better sustainability. Loan demand exceeds the same supply, enabling banks to charge higher interest on loans than deposits to maximize profitability (Musah et al., 2018).

A significant determinant of the banking system's effectiveness in a country is the differential between lending and deposit interest rates, classified as the interest rate spread (IRS). A high IRS poses a severe challenge to the growth of financial intermediation required for an industry to expand and develop. In several countries, the accommodative monetary policy cycle that followed the financial crisis has triggered much dialogue about the possible complications of a (very) low-interest-rate environment on the banking system, notably when sustained for a prolonged period (Altavilla et al., 2018). In the 1990s, the Financial Sector Reform Program (FSRP) allowed banks to set interest rates for lending and depositing within brackets defined by the Bangladesh Bank. Later on, in 1999, other limitations were lifted, enabling banks to set interest rates. The sector was largely excluded from the preceding era's administered interest rate regime to minimize financial intermediation costs and ensure a fair lending and deposit rate structure. The level and the structure of interest rates were managed. Besides, actual deposit and lending rates have been positive recently, with an upward change in nominal interest rates and declines in the inflation rate. The central bank's prudent regulatory measure, including flexible lending \& deposit rate guidance, has made the PCBs sound in banking operations. For these reasons, they are found profitable in their business.

The research's prime objective is to investigate the relationship between Interest rate spread and banks' financial profitability. The other supportive objectives are as follows:

a) To examine the relationship between the deposit rate and the banks' financial performance in Bangladesh.

b) To investigate the effect of lending rate on banks' financial profitability in Bangladesh.

c) To recommend the suggestions regarding the bank's financial stability and sustainability. 


\section{LITERATURE REVIEW}

The main difference between a bank's interest income that comes from the bank's investment (Lending Rate) and interest expenses that go to the depositor (Deposit Rate) is known as Interest Rate Spread (IRS). IRS is the primary source of income for the banking industry. In recent years in Bangladesh, the IRS has attracted growing attention from researchers and policymakers to measure bank performance and determine banks' intermediation costs and profitability. Banks can handle a higher IRS in developed countries than banks in developing and third world countries (Hanson \& de Rezende Rocha, 1986). Ramadan et al. (2011) concluded that lending activities in the Jordanian banking sector are related to profit. Banks should maintain a significant amount of lending activities (Volume of loans \& advances) to maximize profit.

Banks are positively affected by the loans sold (Angbazo, 1997). Suppose the high returns mean that loan rates are higher than in other areas of the globe for the same period. In that case, high profitability will minimize financial intermediation, which will mean a certain amount of inefficiency in providing financial services (Flamini, 2009). Another paper (Guru et al., 2002) suggested that demand deposits can be a competitive weapon for commercial banks. Banks should concentrate on loans to increase their profit efficiency rather than investing in securities and other subsidiaries.

The market interest rate is the most frequently offered interest rate on deposit accounts, other interest-bearing accounts, including loans \& advances. The supply and demand for loans dictate it. A study documents that the market interest rate (lending rate) has a positive and essential effect on commercial bank profitability and suggested that the market interest rate is one of the significant determinants of commercial banks' profitability (Mayuri \& Vijayakumaran, 2017). A study in the Czech Republic (Kostikov et al., 2019) examined that the interest rate on a consumer loan, the deposit interest rate, and other macroeconomic variables significantly affect the volume of consumer loans mortgages loan. The lending rate has positive and negative impacts on the bank's return on equity $(\mathrm{ROE})$. It explores that the consumer loan rate has a negative impact while the mortgage loan positively impacts ROE.

Mujeri and Younus (2009) found that the higher the non-interest income percentage of a bank's total assets, the lower the spread. The influencing factors of IRS are the market share of a bank's deposit and statutory reserve requirements. Mujeri (2008) mentioned that the high IRS is primarily the product of inefficiencies and a lack of competition in the banking system in the country's banking sector. He also examined that the fundamental causes of the elevated IRS are: elevated administrative costs, classified loan rates, and certain macroeconomic variables. A study concluded that the IRS in Bangladesh's banking sector has been persistently strong over the years, meaning the high cost of intermediation for Bangladesh's banking sector (Ahmed \& Islam, 2006).

It also stated that the IRS in Bangladesh's banking sector is vigorous compared to its neighbouring countries. The inefficiency resulted from the government's interventionist policies of the past and insufficient technological expertise in the risk and portfolio management arena, allowing the banking system to spread widely. A study's findings show that the interest rate gap has risen due to the productivity and high costs of intermediation that have yet to be achieved (Ngugi, 2001). It also reveals that interest spread fluctuations are due to banks' attempts to preserve endangered profit margins. In 
Bangladesh, the IRS was high compared to international standards and Sri Lanka, India, and Pakistan (Afroze, 2013; Nguyen, Islam, \& Ali, 2010).

There are also other ways of measuring the IRS, as we know. For example, banks can measure spread as the difference in percentage terms between their cost incurred due to acquiring customer deposits and interest in giving loans. Cost involves the need to set aside the required reserves for SLR that earn no interest, keep surplus reserves, and low yielding reserves in this regard. However, it is vital to prevent misunderstanding concerning which spreads are taken into account. The net interest margin (NIM) is related, defined as the difference between interest expenditure and interest income per unit of total bank assets. The NIM is seen as a significant indication of intermediation's adeptness. The hope is that as the banking industry matures and competition increases, NIM will decrease.

Despite the elimination of banking sector regulations and adjustments to promote the implementation of a market-oriented policy on interest rates, interest rates have not yet been entirely market-responsive. As the country's banking and financial sector's regulatory authority, the Bangladesh Bank has encouraged banks to reduce the IRS moderately. Despite these efforts, the IRS has remained robust in its banking sector (Rahman, 2007). There are only a few studies in Bangladesh on the IRS, especially identifying the factors behind a high IRS's existence in the country's banking sector. Besides, no reliable statistical study was conducted to identify the factors influencing Bangladesh's IRS. We have used 15 bank deposit rates, loan rates, and spread data from the last eight years, from 2012 to 2019, to describe the IRS in the present paper's Bangladesh banking sector. Initially, the methodology was intended to analyze productivity in the banking sector. Shaffer (1993) used multiple variable regression to find the bank's competencies. This approach was adopted to study IRS in various countries (Shaffer, 1993).

\section{METHODOLOGY}

This paper's analysis is based on panel data of the 15 listed banks over 2012-2019. That means we have only 120 observations for our analysis, which is very limited for this kind of sensitive analysis where numbers are identical to the bank.

\subsection{Population and Sampling}

Sixty-one (61) commercial banks are operating in Bangladesh. Some have been operating from the beginning of the country's liberation, and some have recently started their business. The population of the study includes all the banks of the country. The convenience sampling method was used for the study. The study sample includes the banks listed in the Dhaka Stock Exchange and continued their operation before 2012. The convenience sampling method is used for collecting the relevant data from convenient sources efficiently.

\subsection{Sources of Data and Research Instrument}

All data are collected from a secondary source. For deposit rate advances rate/loan rate and spread, we use the Bangladesh Bank data archive, mainly the statistics department of the Bangladesh bank. The dependent variable Return on Equity (ROE) and Return on Assets (ROA) has been collected from banks' annual reports. The collected data were analyzed using Microsoft excel to reach out with the findings. The time-series data 
collected from fifteen (15) selected private commercial banks from 2012 to 2019 have sufficient observations to analyze the issue.

\subsection{Variable Description}

Table 1. Description of variables

\begin{tabular}{|c|c|c|}
\hline Variable Type & Variable Name & Description \\
\hline \multirow{4}{*}{$\begin{array}{l}\text { Dependent } \\
\text { Variable }\end{array}$} & \multirow{2}{*}{$\mathrm{ROA}$} & Net Income \\
\hline & & $\overline{\text { Total Assets }}$ \\
\hline & \multirow{2}{*}{ ROE } & Net Income \\
\hline & & $\overline{\text { Total Equity }}$ \\
\hline \multirow{3}{*}{$\begin{array}{l}\text { Independent } \\
\text { Variable }\end{array}$} & Deposit Rate & $\begin{array}{l}\text { The rate at which a bank receives money } \\
\text { from customers and gives interest. }\end{array}$ \\
\hline & Lending Rate & $\begin{array}{l}\text { The rate at which a bank lends its money to } \\
\text { the targeted customer and makes the } \\
\text { investment. }\end{array}$ \\
\hline & Interest Rate Spread & $\begin{array}{l}\text { The difference between banks' lending rate } \\
\text { and deposit rate. }\end{array}$ \\
\hline
\end{tabular}

\subsection{Hypotheses of the Study}

The following hypotheses are specified in their null forms will be examined to confirm relevant answers to the research questions and clarify the research objectives:

$\mathbf{H}_{1}$ : There is a significant negative relationship between the deposit rate and commercial banks' profitability.

$\mathbf{H}_{2}$ : There is a significant positive relationship between the lending rate and commercial banks' profitability.

$\mathbf{H}_{3}$ : There is a significant positive relationship between interest rate spread and commercial banks' profitability.

\subsection{Model of Analysis}

The multiple variable regression model is as follows:

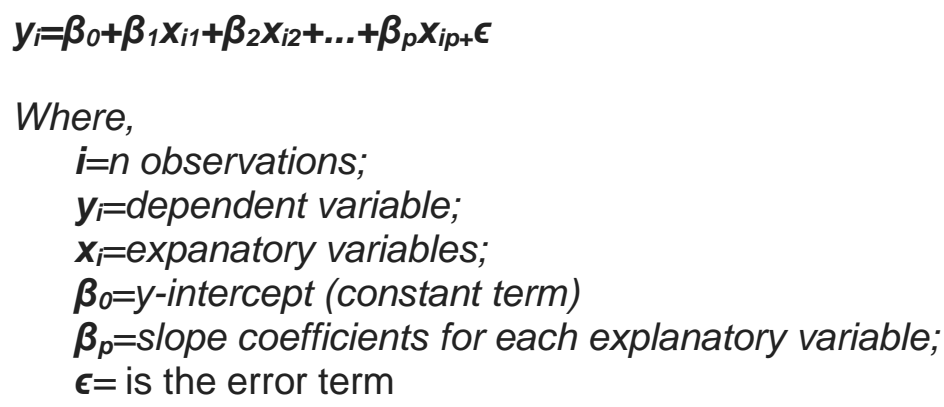

The followings are the model we used in this study Model 1: $R O A=\beta_{0}+\beta_{1}$ (deposit rate $)+\beta_{2}$ (Loan rate $)+\beta_{2}$ (spread rate $)+\epsilon$ Model 2: $R O E=\beta_{0}+\beta_{1}($ deposit rate $)+\beta_{2}($ Loan rate $)+\beta_{2}($ spread rate $)+\epsilon$ 


\section{ANALYSIS AND DISCUSSION}

This section shows various analyses to decide between the hypotheses.

\subsection{Descriptive Statistics}

Table 1 will show basic descriptive statistics for the variable based on panel data from 2012 to 2019 for 15 randomly selected banks. The table represents the mean, median, standard deviation, skewness, and some observations. The following result is based on (i.e., 8 years $\times 15$ banks) 120 observations.

Table 2. Descriptive statistics

\begin{tabular}{llllll}
\hline $\begin{array}{l}\text { Variable } \\
\text { name }\end{array}$ & Mean & Maximum & Minimum & $\begin{array}{l}\text { Std. } \\
\text { deviation }\end{array}$ & Skewness \\
\hline IRS & 5.006389 & 8.316667 & 2.676667 & 1.158728 & 0.628895 \\
Deposit rate & 6.859160 & 10.43250 & 2.304167 & 1.906621 & -0.008240 \\
Loan rate & 11.86241 & 16.78250 & 8.007500 & 2.203778 & 0.289049 \\
ROE & 11.22725 & 23.40000 & -1.150000 & 4.263357 & -0.165601 \\
ROA & 0.909083 & 1.900000 & -0.080000 & 0.353884 & -0.055602 \\
\hline
\end{tabular}

From Table 2, it is seen that ROA and ROE have negative for a bank. The average deposit rate is $6.86 \%$ which is moderate for a bank. The loan rate is more than $11 \%$, which helps the bank sustain in the market, but the 2020 central bank of Bangladesh says all have to main the loan rate in the single-digit that means below $10 \%$. Return on assets indicates the company's capital intensity, which will rely on the industry; businesses needing substantial initial investments will typically have lower asset returns. ROAs over $5 \%$ is generally considered good.

However, our observation has the average ROA is .909083\%, and the maximum ROA is $1.9 \%$. This shows the inefficiencies of our bank. ROE is mainly used for comparing the output of businesses in the same market. As with capital return, and ROE is a measure of management's ability to produce revenue from the equity available to it. Generally, ROEs of 15-20 percent is considered acceptable. In terms of ROE, our selected bank performs well, where the average ROE was $11.22 \%$, and the maximum was $23.40 \%$ that shows efficient the bank is. We can also see that our ROE and ROA also have negative skewness.

\subsection{Pearson's Correlation Coefficient Analysis}

Table 3 shows Pearson's Correlation Coefficient Analysis. It is seen that interest rate spread has a significant positive correlation with banks' profitability. Our primary concern is the relationship between the interest rate and profitability. We can look into these ratios, the correlation between spread and ROE, ROA is 0.265 and 0.225 respectively, which indicate a 0.26 and 0.22 -degree positive relationship. If spread increases by 1 unit, ROE and ROA will increase by 0.26 and 0.22 units, respectively. Therefore, it can be said that there is a significant positive correlation between interest rate spread and banks' profitability. Another correlation could be observed that the deposit rate negatively relates to $\mathrm{ROE}$ and interest rate spread. This indicates that if the deposit rate increased by 1 unit, spreads and ROE will decrease by .100 and .029 , respectively and vice-versa. 
Table 3. Pearson's Correlation Coefficient Analysis

\begin{tabular}{llllll}
\hline Correlation & ROA & ROE & Spread & Loan Rate & Deposit Rate \\
\hline ROA & 1 & $.840^{* *}$ & $.225^{*}$ & .196 & .094 \\
ROE & $.840^{* *}$ & 1 & $.265^{* *}$ & .049 & -.100 \\
Spread & $.225^{*}$ & $.265^{* *}$ & 1 & $.503^{* *}$ & -.029 \\
Loan Rate & $.196^{*}$ & .049 & $.503^{* *}$ & 1 & $.848^{* *}$ \\
Deposit Rate & .094 & -.100 & -.029 & $.848^{* *}$ & 1 \\
\hline
\end{tabular}

Correlation is significant at the 0.01 level (2-tailed)..*

Correlation is significant at the 0.05 level (2-tailed).*

\subsection{Regression Analysis}

The regression results in Table 4 show that the explanatory variable Deposit rate \& interest rate spread (IRS) have a statistically significant positive effect on banks' profitability. For our model probability (F-statistics), respectively 0.045 and 0.012 , lower than $5 \%$, which means the model does not suffer from specification bias, respectively. For both model 1 and model 2, the deposit rate, loan rate, and spread are the explanatory variable. ROA and ROE are dependent variables. In model 1 , R-squared is 0.067 , which means $6.63 \%$ variation in ROA can explain our variable, which is not enough. In model 2 , that is $9 \%$ variation can explain by the variables. To explain $f$ statistics, $4.6 \%$ and $1.2 \%$ means our variable jointly influences the dependent variable. Model 1 describes that there is a significant impact of independent variables on the dependent variable ROA. The adjusted $R$ square value is 0.43 , which means only 4.3 percent of the dependent variable variance is explained by independent variables.

Table 4. Regression Analysis

\begin{tabular}{|c|c|c|c|c|c|c|c|c|c|}
\hline \multirow[b]{2}{*}{ Model } & \multirow[b]{2}{*}{$\mathrm{R}$} & \multirow[b]{2}{*}{ R Square } & \multirow[b]{2}{*}{$\begin{array}{l}\text { Adjusted R } \\
\text { Square }\end{array}$} & \multirow[b]{2}{*}{$\begin{array}{l}\text { Std. Error of the } \\
\text { Estimate }\end{array}$} & \multicolumn{5}{|c|}{ Change Statistics } \\
\hline & & & & & $\begin{array}{l}\text { R Square } \\
\text { Change }\end{array}$ & F Cha & e df1 & df2 & $\begin{array}{l}\text { Sig. F } \\
\text { Change }\end{array}$ \\
\hline 1 & $.258^{a}$ & .067 & .043 & .34 & .067 & 2.7 & 3 & 116 & .045 \\
\hline$\underline{2}$ & $.299^{\mathrm{a}}$ & .090 & .066 & 4.12005 & .090 & 3.807 & 3 & 116 & .012 \\
\hline
\end{tabular}

The equation employs ROA as its dependent variable. Simultaneously, deposit rate, lending rate, and interest rate spread are the independent variables. For the model, the probability (F-statistics) value (0.045) significant at the $5 \%$ level shows that the model does not suffer from measurement bias. However, from model 2, the coefficient of determination (R2) indicates that the explanatory variables account for about $9 \%$ of the ROE change. In comparison, the adjusted R-squared of $6.6 \%$ further justifies this effect. The P-value of this model is .012, which is lower than $5 \%$. The result indicates that this study cannot accept the null hypothesis. Therefore, it can be said that the independent variables have a significant statistical impact on the banks' profitability.

This study mainly focuses on $x$-ray the relationship of interest rate spread, the difference between the lending rate and the deposit rate with commercial banks' financial performance. Banks with a higher volume of profitability will sustain better than banks with a lower level of profitability. A two linear regression model is developed with three hypotheses to decide the relationship between IRS and banks' profitability. The regression analysis result shows that both models are statistically significant, revealing that deposit rate, lending rate, and interest rate significantly impact the banks' financial performance. The correlation matrix shows that IRS and loan rates are significantly positively correlated 
with both ROA and ROE. In contrast, the deposit rate is positively correlated with ROA but negatively correlated with ROE.

\section{FINDINGS AND RECOMMENDATIONS}

The findings and recommendations of the study are discussed as follows:

\subsection{Findings of the study}

The results of models 1 and 2 show a negative relationship between the Loan rate and bank profitability (ROE and ROA). There is a positive relationship between the loan rate and profitability (Hester \& Zoellner, 1966). Our model shows the positive relationship between the spread rate, the difference between the lending rate and deposit rate. This shows higher spread rate can bring the best profitability for a commercial bank. A bank can maintain a higher spread in a two-way lower deposit rate or the higher loan rate.

Table 5. Findings of the study

\begin{tabular}{ll}
\hline Hypothesis & Validation \\
\hline $\mathbf{H}_{1}$ : There is a significant negative relationship between the deposit & Not Confirmed \\
rate and commercial bank's profitability. & \\
$\mathbf{H}_{2}:$ There is a significant positive relationship between the lending & Confirmed \\
rate and commercial bank's profitability. & \\
$\mathbf{H}_{3}:$ There is a significant positive relationship between interest rate & Confirmed \\
spread and commercial bank's profitability. &
\end{tabular}

\subsection{Recommendations of the Study}

The study also brings some recommendations according to analysis, and these are as follows:

a) Banks should revise their lending rate in the context of the current market situation.

b) Banks should make their investment to make a higher level of profit margin that can enhance their efficiency of management and financial soundness.

c) The deposit rate should be determined by maintaining a positive gap between the deposit and lending rates.

d) Banks should focus on the other income sources rather than interest rate spread to sustain the market in the long run.

e) Bangladesh Bank should relax its guidelines on a single-digit interest rate for banks' to maintain the excellent health of the banking industry.

\section{CONCLUSION}

The study identifies several determinants underlying the persistence of high IRS in Bangladesh's banking sector. During the data collection period, it is observed that inefficiencies and inadequate rivalry among the banks are essential for high IRS in the country's banking sector. In recent years, the banks' regular deposit rate in actual terms has fallen gradually due to high inflation. The scope of dropping the IRS by reducing the deposit rate would be counterproductive. It is also important to recognize that the banks are free to set both lending and deposit rates according to market conditions within the market-determined interest rate policy regime currently pursued by the Bangladesh Bank. However, this year, banks are not free to set lending rates as the central bank set the ceiling level for the lending rate that is a single digit that means lower than 10 percent. In 
such a situation, tools available to Bangladesh Bank for influencing the interest rate structure are somewhat limited in number. It would be helpful to urge the banks to become more aware of and responsive to their corporate social responsibility. This is necessary to strengthen the local banks, mainly because of the increasing competition the local banks will have to withstand as the banking sector opens up through reform.

This study shows the relationship between market interest rates with banks' financial performance. It is found that the interest rate spread is positively associated with the profitability of a bank measured by ROA and ROE and implies higher interest rate spread would increase profitability. It is also examined that the lending rate, deposit rate, and interest rate spread significantly impact the banks' profitability. There is a strong connection between the interest rate spread and the banks' performance. Therefore, it is recommended that banks set a standard lending rate to maintain a gap with the deposit rate to improve banks' performance. They should revise their deposit rate and lending rate in the current market to maintain their financial stability. Finally, it has been concluded that the market interest rate is a strong determinant of banks' financial performance, having a remarkable impact on the banks' profitability.

\section{REFERENCES}

Afroze, R. (2013). Interest Rate Spread of Commercial Banks: Empirical Evidence from Bangladesh. ASA University Review, 7(2).

Ahmed, S., \& Islam, M. E. (2006). Interest Rate Spread in Bangladesh: An Analytical Review. Bangladesh Bank Quarterly, 22-28.

Altavilla, C., Boucinha, M., \& Peydró, J. L. (2018). Monetary policy and bank profitability in a low-interest-rate environment. Economic Policy, 33(96), 531-586.

Angbazo, L. (1997). Commercial bank net interest margins, default risk, interest-rate risk, and off-balance sheet banking. Journal of Banking \& Finance, 21(1), 55-87.

Bb.org.bd. 2020. [online] Available at: <https://www.bb.org.bd/econdata/index.php> [Accessed 19 December 2020].

Bbs.gov.bd. 2020. Bangladesh Bureau of Statistics. [online] Available at: <http://www.bbs.gov.bd/site/page/dc2bc6ce-7080-48b3-9a04-73cec782d0df/Gross-Domestic-Product(GDP)> [Accessed 18 December 2020].

Flamini, V., McDonald, C. A., \& Schumacher, L. B. (2009). The determinants of commercial bank profitability in Sub-Saharan Africa. IMF Working Papers, 1-30.

Guru, B. K., Staunton, J., \& Balashanmugam, B. (2002). Determinants of commercial bank profitability in Malaysia. Journal of Money, Credit, and Banking, 17(1), 69-82.

Hanson, J. A., \& de Rezende Rocha, R. (1986). High-interest rates, spreads, and the costs of intermediation: Two studies (No. IAF18, pp. 1-94). The World Bank.

Hester, D. D., \& Zoellner, J. F. (1966). The relation between bank portfolios and earnings: an econometric analysis. The review of Economics and Statistics, 372-386.

Kostikov, E., Jílková, P., \& Kotátková, S. P. (2019). Quantified impact of market interest rates on commercial banks' business mix. Journal of International Studies, 12(2).

Mujeri, M. K., \& Islam, M. E. (2008). Rationalizing Interest Rate Spread in the Banking Sector: Some Policy Suggestions. Policy Paper No, 804.

Mujeri, M. K., \& Younus, S. (2009). An analysis of interest rate spread in the banking sector in Bangladesh. The Bangladesh Development Studies, 1-33.

Musah, A., Anokye, F. K., \& Gakpetor, E. D. (2018). The Impact of Interest Rate Spread on Bank Profitability in Ghana. European Journal of Business, Economics and Accountancy, 6(1), 27-39.

Ngugi, R. W. (2001). An empirical analysis of interest rate spread in Kenya.

Nguyen, C. V., Islam, A. M., \& Ali, M. M. (2010). Bangladeshi lending-deposit rate spread: an econometric analysis. Global Economy and Finance Journal, 3(2), 238-246.

Rahman, M. (2007). Financial Development: Economic Growth Nexus in Bangladesh. Policy Analysis Unit (PAU) Working Paper No. WP, 707.

Ramadan, I. Z., Kilani, Q. A., \& Kaddumi, T. A. (2011). Determinants of Bank Profitability: Evidence From Jordan. International Journal of Academic Research, 3(4).

Shaffer, S. (1993). A test of competition in Canadian banking. Journal of Money, Credit and Banking, 25(1), 49-61. 
Saha, D., Bishwas, P.C., \& Sumon, M. M. A.

Tan, Y., \& Floros, C. (2012). Bank profitability and GDP growth in China: a note. Journal of Chinese Economic and Business Studies, 10(3), 267-273. 